\title{
Shared Genomic Architectures of Covid-19 and Antisocial Behavior: Implications During Pandemics
}

\section{Authors}

Charleen D. Adams, $\mathrm{PhD} \mathrm{MPH}^{1}$, Jorim J. Tielbeek, $\mathrm{PhD}^{2}$, Brian B. Boutwell, $\mathrm{PhD}^{3,4}$

${ }^{1}$ Department of Environmental Health, Program in Molecular and Integrative Physiological

Sciences, Harvard T.H. Chan School of Public Health, Boston, Massachusetts 02115, USA; ${ }^{2}$

Department of Complex Trait Genetics, Center for Neurogenomics and Cognitive Research,

Amsterdam Neuroscience, Vrije Universiteit Amsterdam, Amsterdam, Netherlands; ${ }^{3}$ School of

Applied Sciences, The University of Mississippi P.O. Box 1848, University, MS, 38677, USA; ${ }^{4}$

John D. Bower School of Population Health, University of Mississippi Medical Center, Jackson,

MS, 39216, USA

Correspondence to:

Department of Environmental Health, Program in Molecular and Integrative Physiological

Sciences, Harvard T.H. Chan School of Public Health, Boston, Massachusetts 02115, USA; Tel.:

626-841-3937; Email: cdadams@hsph.harvard.edu. 


\begin{abstract}
BACKGROUND. Norm violation, aggression, and antisocial behaviors (ASB) are harmful to society. In times of crisis, such as the current pandemic, individuals with higher antisocial tendencies may subvert efforts to ameliorate social problems. Complicating research on this topic, however, is the fact that variance in both ASB and health traits is partly heritable, suggesting the possibility of genetic correlations between them.
\end{abstract}

METHODS. We characterized the shared polygenic architecture of ASB, Covid-19, and related traits, leveraging summary statistics from genome-wide association studies.

RESULTS. After multiple-testing correction, ASB was genetically correlated with average income $\left(r_{g}=-0.54 ; 95 \%\right.$ confidence interval $\left.[\mathrm{CI}]:-0.65,-0.43\right)$; education years $\left(r_{g}=-0.48\right.$; CI: 0.59, -0.38; verbal reasoning $\left(r_{g}=-0.44\right.$; CI: $\left.-0.58,-0.30\right)$; healthspan $\left(r_{g}=-0.47\right.$; CI: $\left.-0.62,-0.31\right)$, lifespan $\left(r_{g}=-0.33\right.$ (CI: $\left.-0.46,-0.21\right)$; breastfed as baby $\left(r_{g}=-0.24 ; 95 \%\right.$ CI: $\left.-0.38,-0.11\right)$; cheese intake ( $r_{g}=-0.28$ (CI: $\left.-0.38,-0.18\right)$; Covid-19 $\left(r_{g}=0.51,95 \%\right.$ CI: 0.12, 0.90; heavy, manual labor $\left(r_{g}=0.58\right.$; CI: $\left.0.45,0.70\right)$; noisy workplace $\left(r_{g}=0.63\right.$; CI: $\left.0.48,0.77\right)$; Townsend Deprivation Index $\left(r_{g}=0.70\right.$; CI: 0.56, 0.84); gastrointestinal diseases $\left(r_{g}=0.46 ; 95 \%\right.$ CI: $\left.0.23,0.70\right)$; chronic obstructive pulmonary disease $\left(r_{g}=0.51\right.$; CI: $\left.0.33,0.68\right)$; genitourinary diseases $\left(r_{g}=0.38 ; \mathrm{CI}\right.$ : 0.22, 0.55); neuroticism $\left(r_{g}=0.29\right.$; CI: 0.20, 0.38); seen doctor for nerves, anxiety, tension, or depression $\left(r_{g}=0.42\right.$; CI: $\left.0.31,0.54\right)$; plays computer games $\left(r_{g}=0.15\right.$; CI: $\left.0.06,0.25\right)$; violentcrime victim $\left(r_{g}=0.36\right.$; CI: $\left.0.16,0.56\right)$; risk tolerance $\left(r_{g}=0.50 ; \mathrm{CI}: 0.39,0.65\right)$; saw sudden violent death $\left(r_{g}=0.42 ; \mathrm{CI}: 0.20,0.64\right)$.

CONCLUSIONS. Our results suggest ASB shares genetic architecture with Covid-19 and related health outcomes. We discuss the public-health and bioethical implications of our results. 
medRxiv preprint doi: https://doi.org/10.1101/2021.10.18.21265145; this version posted October 19, 2021. The copyright holder for this preprint (which was not certified by peer review) is the author/funder, who has granted medRxiv a license to display the preprint in perpetuity.

All rights reserved. No reuse allowed without permission.

Antisocial behavior (ASB), including aggression, rule-breaking, and violence, is harmful to society. ASB creates a long wake of monetary, social, and emotional disturbances for countries, communities, and individuals ${ }^{1,2}$. An oft-overlooked yet troublesome consequence of ASB concerns its effect on efforts to solve widespread social problems, such as during a pandemic. To contain the present pandemic, the World Health Organization (WHO) recommended various protective measures against coronavirus disease 2019 (Covid-19). These included masking, avoiding crowds, physical distancing, and Covid-19 vaccination—behaviors that can be seen as prosocial, as they function to keep both individuals and others free from infection. Yet ASB, as its name implies, reflects the converse of prosocial and cooperative behavior. Mechanisms by which ASB might impact pandemic spread are numerous and in general, they remain largely understudied.

Concerning how ASB may abet pandemic spread, O’Connell et al. (2021) reported that those in an online US cohort who engaged more in ASB also more frequently ignored Covid-19 social-distancing measures ${ }^{3}$. Likewise using an online cohort, Carvalho and Machado (2020) found that those with increased psychopathic traits and low levels of empathy tended to adhere less to Covid-19 containment measures ${ }^{4}$. As a final example, Nivette et al. (2020) observed that adolescents and young adults (in a prospective-longitudinal cohort in Switzerland), who had previously scored high on indicators of antisociality (i.e., low acceptance of moral rules, "prepandemic legal cynicism, low shame/guilt, low self-control, engagement in delinquent behaviors, and association with delinquent peers"), were more likely to flout Covid-19 public-health measures ${ }^{5}$. These findings imply that a lack of understanding about ASB and health outcomes could imperil public-health efforts during pandemics. 
medRxiv preprint doi: https://doi.org/10.1101/2021.10.18.21265145; this version posted October 19, 2021. The copyright holder for this preprint (which was not certified by peer review) is the author/funder, who has granted medRxiv a license to display the preprint in perpetuity.

All rights reserved. No reuse allowed without permission.

Complicating efforts at causal inference on this topic, however, is the fact that about half of the variance in ASB and health outcomes (to varying degrees depending on the trait) is heritable ${ }^{6-8}$. The extent to which these traits share a genetic architecture could influence the likelihood of genetic confounding in observational data. A nascent area of research has used the summary statistics from genome-wide association (GWA) studies of ASB and various health and behavioral traits to calculate genetic correlations ${ }^{9}$. These studies revealed links between ASB and most psychiatric and psychological, reproductive, cognitive, and addictive traits ${ }^{10,11}$. Individuals prone to antisocial, violent, and criminal behaviors are also disproportionately and profoundly unhealthy $^{12,13}$, and a recent study reported strong negative $(r=-0.55)$ genetic correlations between ASB and self-reported health ${ }^{10}$. In contrast, a comprehensive study reported no significant genetic correlations between ASB and 669 health, physiological, and well-being measures after accounting for multiple testing ${ }^{14}$. Thus, much remains to be discovered regarding any shared genetic etiology of ASB and various aspects of health, including Covid-19.

\section{Methods}

We characterized the shared polygenic nature of ASB, Covid-19, and related health and behavioral traits using summary statistics from GWA studies and linkage disequilibrium score regression (LDSC; software available at http://www.github.com/bulik/ldsc) ${ }^{15}$. We calculated a matrix of the genetic correlations. Nineteen traits were chosen for novelty (having not been previously reported as either null or significantly correlated with ASB), and four traits were chosen as replicates of previously reported findings (education years; seen doctor for nerves, anxiety, tension, or depression; neuroticism; Parkinson's disease). The novel traits include: average income (before taxes): healthspan (defined as living free from congestive heart failure; myocardial infarction, chronic obstructive pulmonary disease, stroke, dementia, diabetes, cancer, 
medRxiv preprint doi: https://doi.org/10.1101/2021.10.18.21265145; this version posted October 19, 2021. The copyright holder for this preprint (which was not certified by peer review) is the author/funder, who has granted medRxiv a license to display the preprint in perpetuity.

All rights reserved. No reuse allowed without permission.

and death; coded as a protective ratio); parental lifespan (coded as a protective ratio); verbal reasoning; having been breastfed as baby; cheese intake; self-reported happiness; Covid-19 (data from two GWA studies; see Table 1); heavy, manual labor; noisy workplace; Townsend Deprivation Index (an area- and census-based measure of deprivation, where a higher score indicates more deprivation); gastrointestinal diseases; chronic obstructive pulmonary disease; genitourinary diseases; plays computer games, violent-crime victim, risk tolerance, and saw sudden, violent death. Table 1 contains details about the GWA studies-all performed in those of European ancestry.

\section{Results}

Figure 1 is a heatmap showing how the genetic correlations for the traits cluster together. Tables 1-2 in the Supplementary Appendix contain the genetic correlations and SNP heritability estimates (all >0) for traits in Figure 1. (We refer readers to the Supplementary Appendix for many of the non-ASB correlations.) Figure 2 displays the genetic correlations for ASB and the 23 traits in a forest plot, grouped by how they clustered in the heatmap (Figure 1).
ASB
ASB was negatively genetically correlated with nine traits, of which seven were significant after FDR correction at $P<0.05$ (the $P$-values provided are the FDR-corrected values): average income $\left(r_{g}=-0.54 ; 95 \%\right.$ confidence interval $[\mathrm{CI}]:-0.65,-0.43$; $\left.P=9.88 \mathrm{E}-22\right)$; education years $\left(r_{g}=-0.48 ; 95 \% \mathrm{CI}:-0.59,-0.38 ; P=9.76 \mathrm{E}-20\right)$; verbal reasoning $\left(r_{g}=-0.44 ; 95 \% \mathrm{CI}:-0.58,-\right.$ $0.30 ; P=5.62 \mathrm{E}-09)$; healthspan $\left(r_{g}=-0.47 ; 95 \% \mathrm{CI}:-0.62,-0.31 ; P=5.97 \mathrm{E}-09\right)$ and lifespan $\left(r_{g}=-\right.$ 0.33 (95\% CI: $-0.46,-0.21 ; P=4.20 \mathrm{E}-07)$; breastfed as baby $\left(r_{g}=-0.24 ; 95 \%\right.$ CI: $-0.38,-0.11$; $P=9.60 \mathrm{E}-04)$; cheese intake $\left(r_{g}=-0.28\right.$ (95\% CI: $\left.-0.38,-0.18 ; P=6.97 \mathrm{E}-08\right)$; happiness $\left(r_{g}=-0.10\right.$; 
95\% CI: $-0.25,0.05 ; P=2.22 \mathrm{E}-01)$; and Parkinson's disease $\left(r_{g}=-0.04 ; 95 \%\right.$ CI: $-0.25,0.18 ; P=$ 7.77E-01).

ASB was positively genetically correlated with 14 traits, of which 13 were significant after FDR correction and one, Covid-19 (round 6), was marginally significant prior to FDR correction: Covid-19 (round 4) $\left(r_{g}=0.51,95 \%\right.$ CI: 0.12, 0.90; $P=1.54 \mathrm{E}-02$; Covid-19 (round 6) $\left(r_{g}=0.35 ; 95 \%\right.$ CI: $\left.0.02,0.68 ; P=5.21 \mathrm{E}-02\right)$; doing heavy, manual labor $\left(r_{g}=0.58 ; 95 \%\right.$ CI: 0.45 , $0.70 ; P=8.31 \mathrm{E}-19)$; having a noisy workplace $\left(r_{g}=0.63 ; 95 \% \mathrm{CI}: 0.48,0.77 ; P=3.99 \mathrm{E}-16\right)$; Townsend Deprivation Index $\left(r_{g}=0.70 ; 95 \%\right.$ CI: 0.56, 0.84; $\left.P=2.25 \mathrm{E}-22\right)$; gastrointestinal diseases $\left(r_{g}=0.46 ; 95 \% \mathrm{CI}: 0.23,0.70 ; P=1.89 \mathrm{E}-04\right)$; chronic obstructive pulmonary disease $\left(r_{g}=0.51 ; 95 \%\right.$ CI: $\left.0.33,0.68 ; P=6.45 \mathrm{E}-08\right)$; genitourinary diseases $\left(r_{g}=0.38 ; 95 \%\right.$ CI: $0.22,0.55$; $P=1.45 \mathrm{E}-05)$; neuroticism $\left(r_{g}=0.29 ; 95 \%\right.$ CI: $\left.0.20,0.38 ; P=3.05 \mathrm{E}-10\right)$; seen doctor for nerves, anxiety, tension, or depression $\left(r_{g}=0.42 ; 95 \% \mathrm{CI}: 0.31,0.54 ; P=2.36 \mathrm{E}-13\right)$; plays computer games $\left(r_{g}=0.15 ; 95 \%\right.$ CI: $\left.0.06,0.25 ; P=3.60 \mathrm{E}-03\right)$; being a violent-crime victim $\left(r_{g}=0.36 ; 95 \%\right.$ CI: $0.16,0.56 ; P=5.82 \mathrm{E}-04)$; risk tolerance $\left(r_{g}=0.50 ; 95 \%\right.$ CI: $\left.0.39,0.60 ; P=6.34 \mathrm{E}-20\right)$; and seeing a sudden, violent death $\left(r_{g}=0.42 ; 95 \%\right.$ CI: $\left.0.20,0.65 ; P=3.95 \mathrm{E}-04\right)$.

\section{Covid-19}

Due to the positive genetic signal between Covid-19 and ASB, we highlight the correlations between Covid-19 and the non-ASB traits. These are displayed in a forest plot in

\section{Figure 3 .}

Covid-19 was statistically significant after FDR-correction (for at least one of the Covid19 measures) and negatively genetically correlated with average income $\left(r_{g}\right.$, round $4=-0.16 ; 95 \%$ CI: $-0.32,-0.004 ; P=6.02 \mathrm{E}-02 ; r_{g}$, round $6=-0.21 ; 95 \%$ CI: $\left.-0.37,-0.04 ; P=2.06 \mathrm{E}-02\right)$; education years $\left(r_{g}\right.$, round $4=-0.32 ; 95 \%$ CI: $-0.48,-0.16 ; P=1.39 \mathrm{E}-04 ; r_{g}$, round $6=-0.46 ; 95 \%$ CI: -0.66 , - 
0.26; $P=1.09 \mathrm{E}-05)$; verbal reasoning $\left(r_{g}\right.$, round $4=-0.28 ; 95 \% \mathrm{CI}:-0.52,-0.03 ; P=3.79 \mathrm{E}-02 ; r_{g}$, round $6=-0.49 ; 95 \% \mathrm{CI}:-0.76,-0.22 ; P=6.28 \mathrm{E}-04)$; healthspan $\left(r_{g}\right.$, round $4=-0.25 ; 95 \% \mathrm{CI}:-$ $0.45,-0.04 ; P=2.53 \mathrm{E}-02 ; r_{g}$, round $6=-0.41 ; 95 \%$ CI: $\left.-0.62,-0.20 ; P=2.23 \mathrm{E}-04\right) ;$ lifespan $\left(r_{g}\right.$, round $4=-0.17 ; 95 \% \mathrm{CI}:-0.37,0.04 ; P=1.47 \mathrm{E}-01 ; r_{g}$, round $6=-0.30 ; 95 \% \mathrm{CI}:-0.48,-0.11$; $P=2.73 \mathrm{E}-03)$; being breastfed as baby $\left(r_{g}\right.$, round $4=-0.17 ; 95 \% \mathrm{CI}:-0.41,0.06 ; P=1.93 \mathrm{E}-01 ; r_{g}$, round $6=-0.24 ; 95 \% \mathrm{CI}:-0.46,-0.03 ; P=3.69 \mathrm{E}-02)$; and cheese intake $\left(r_{g}\right.$, round $4=-0.36 ; 95 \%$ CI: $-0.56,-0.16 ; P=9.65 \mathrm{E}-04 ; r_{g}$, round $6=-0.39 ; 95 \%$ CI: $\left.-0.59,-0.20 ; P=1.88 \mathrm{E}-04\right)$.

Most of the positive correlations between Covid-19 and traits were null, including for the following: happiness $\left(r_{g}\right.$, round $4=0.06 ; 95 \% \mathrm{CI}:-0.19,0.30 ; P=7.07 \mathrm{E}-01 ; r_{g}$, round $6=0.03 ; 95 \%$ CI: $-0.21,0.27 ; P=8.38 \mathrm{E}-01)$; Parkinson's disease $\left(r_{g}\right.$, round 4=0.01; 95\% CI: $-0.26,0.27$; $P=9.59 \mathrm{E}-01 ; r_{g}$, round 6=-0.06; 95\% CI: $\left.-0.28,0.16 ; P=6.61 \mathrm{E}-01\right)$; Townsend Deprivation Index $\left(r_{g}\right.$, round $4=0.08 ; 95 \% \mathrm{CI}:-0.11,0.27 ; P=4.81 \mathrm{E}-01 ; r_{g}$, round $6=0.18 ; 95 \% \mathrm{CI}:-0.05,0.41$; $P=1.66 \mathrm{E}-01)$; gastrointestinal diseases $\left(r_{g}\right.$, round $4=-0.08 ; 95 \% \mathrm{CI}:-0.39,0.24 ; P=7.06 \mathrm{E}-01 ; r_{g}$, round $6=0.20 ; 95 \% \mathrm{CI}:-0.10,0.49 ; P=2.36 \mathrm{E}-01)$; neuroticism $\left(r_{g}\right.$, round 4=-0.09; 95\% CI: -0.26 , $0.08 ; P=3.68 \mathrm{E}-01 ; r_{g}$, round 6=-0.04; 95\% CI: $\left.-0.16,0.08 ; P=5.25 \mathrm{E}-01\right)$; seen doctor for nerves, anxiety, tension, or depression $\left(r_{g}\right.$, round $4=0.03 ; 95 \%$ CI: $-0.11,0.17 ; P=7.22 \mathrm{E}-01 ; r_{g}$, round $6=0.05$; 95\% CI: $-0.09,0.18 ; P=5.40 \mathrm{E}-01)$; plays computer games $\left(r_{g}\right.$, round $4=-0.03$; $95 \%$ CI: $0.17,0.11 ; P=7.19 \mathrm{E}-01 ; r_{g}$, round $\left.6=-0.04 ; 95 \% \mathrm{CI}:-0.17,0.09 ; P=6.23 \mathrm{E}-01\right)$; being a violentcrime victim $\left(r_{g}\right.$, round $4=-0.24 ; 95 \%$ CI: $-0.58,0.11 ; P=2.24 \mathrm{E}-01 ; r_{g}$, round $6=-0.23 ; 95 \%$ CI: $0.09,0.55 ; P=1.97 \mathrm{E}-01)$; risk tolerance $\left(r_{g}\right.$, round $4=0.07 ; 95 \% \mathrm{CI}:-0.10,0.24 ; P=4.97 \mathrm{E}-01 ; r_{g}$, round $6=0.14 ; 95 \% \mathrm{CI}:-0.03,0.31 ; P=1.31 \mathrm{E}-01)$; and seeing a sudden, violent death $\left(r_{g}\right.$, round 4=-0.30; 95\% CI: $-0.68,0.07 ; P=1.50 \mathrm{E}-01 ; r_{g}$, round $6=0.25 ; 95 \%$ CI: $\left.-0.08,0.58 ; P=1.70 \mathrm{E}-01\right)$. 
After FDR-correction, Covid-19 was statistically significant (for at least one of the Covid-19 measures) and positively genetically correlated with the following: doing heavy, manual labor $\left(r_{g}\right.$, round $4=0.20$; 95\% CI: $0.03,0.37 ; P=2.65 \mathrm{E}-02 ; r_{g}$, round $6=0.38 ; 95 \% \mathrm{CI}$ : $0.19,0.56 ; P=1.25 \mathrm{E}-04)$; having a noisy workplace $\left(r_{g}\right.$, round $4=0.26 ; 95 \%$ CI: $0.03,0.49$; $P=3.69 \mathrm{E}-02 ; r_{g}$, round $\left.6=0.28 ; 95 \% \mathrm{CI}: 0.07,0.50 ; P=1.45 \mathrm{E}-02\right)$; chronic obstructive pulmonary disease $\left(r_{g}\right.$, round $4=0.33 ; 95 \%$ CI: $0.04,0.61 ; P=3.44 \mathrm{E}-02 ; r_{g}$, round $6=0.40 ; 95 \%$ CI: 0.11 , $0.70 ; P=1.17 \mathrm{E}-02)$; and genitourinary diseases $\left(r_{g}\right.$, round $4=0.21 ; 95 \% \mathrm{CI}:-0.03,0.45 ; P=1.17 \mathrm{E}-$ $01 ; r_{g}$, round $6=0.32 ; 95 \%$ CI: $\left.0.04,0.60 ; P=3.69 \mathrm{E}-02\right)$.

\section{Parkinson's disease}

To contrast them in the Discussion with the findings for ASB and Covid-19, we report the FDR-significant findings for Parkinson's disease. We observed positive genetic correlations between Parkinson's disease and two traits: average income $\left(r_{g}=0.17 ; 95 \%\right.$ CI: $0.07,0.28$; $P=2.55 \mathrm{E}-03)$; and education years $\left(r_{g}=0.13 ; 95 \% \mathrm{CI}: 0.04,0.23 ; P=1.05 \mathrm{E}-02\right)$. The genetic correlations between Parkinson's disease and three traits were inversely related: heavy, manual labor $\left(r_{g}=-0.15 ; 95 \%\right.$ CI: $-0.27,-0.03 ; P=2.06 \mathrm{E}-02$; Townsend Deprivation Index $\left(r_{g}=-0.21 ; 95 \%\right.$ CI: $-0.34,-0.09 ; P=1.33 \mathrm{E}-03)$; and chronic obstructive pulmonary disease $\left(r_{g}=-0.21 ; 95 \%\right.$ CI: $0.39,-0.04 ; P=2.46 \mathrm{E}-02)$.

\section{Discussion}

In support of the observational findings by O'Connell et al. $(2021)^{3}$, Carvalho and Machado $(2020)^{4}$, and Nivette et al. $(2020)^{5}$, the positive genetic correlation between ASB and Covid-19 suggests that individuals who engage in ASB appear more susceptible to Covid-19 than those who do not engage in ASB. This implies they may put themselves and others at higher 
medRxiv preprint doi: https://doi.org/10.1101/2021.10.18.21265145; this version posted October 19, 2021. The copyright holder for this preprint (which was not certified by peer review) is the author/funder, who has granted medRxiv a license to display the preprint in perpetuity.

All rights reserved. No reuse allowed without permission.

risk and/or that the health conditions associated with ASB, such as chronic obstructive pulmonary disease, make those prone to ASB an at-risk group for Covid-19.

Controversially though rationally, this information could be used to back Covid-19 vaccine mandates. While the traits jointly inversely associated with Covid-19 and ASB-most saliently, education years, reasoning ability, and average income-are environmentally modifiable, this worked against the poor and undereducated during the Covid-19 pandemic (e.g., low-wage workers disproportionately lost their jobs ${ }^{16}$, and learning was hampered by school shutdowns, especially among the most disadvantaged ${ }^{17}$ ). This implies that policies to increase income and education would need to be ramped up and accelerated in times of pandemics, precisely when resources are strained, if increasing income and education are to be used to encourage compliance with prosocial pandemic guidelines.

Observationally, income inequality correlates with types of ASB, most notably crime ${ }^{18}$, but whether economic interventions, such as the federally issued stimulus checks given to a bulk of US citizenry during the Covid-19 pandemic, reduced vaccine hesitancy and social-distancing non-compliance among those prone to ASB is unknown. While addressing that counterfactual is beyond the scope of this paper, what is known is that vaccine mandates for other diseases seem to have been effective at increasing the number of those vaccinated and reducing the populationburden of infectious diseases ${ }^{19,20}$.

That the genetic correlation between Covid-19 and risk tolerance (a characteristic of ASB) was null suggests that a lack of education and not a propensity for risk-taking behavior may link ASB and spread of Covid-19. This is somewhat hopeful: the aspect of antisociality positively associated with getting Covid-19 does not appear to arise from overt risk-seeking, but from a lack of understanding about a complex issue. Perhaps over the coming years, as 
misinformation and conspiracy theories about the safety of Covid-19 vaccines die down, the question about the need for vaccine mandates may become less relevant. On the other hand, introducing vaccine mandates earlier during future pandemics supports both global health and health equity: it would protect many of the least advantaged, including and especially those prone to ASB. Further to this, traits that are positively genetically correlated with both ASB and Covid-19—having a noisy workplace, doing heavy, manual labor, and having chronic obstructive pulmonary disease_-are also strongly inversely genetically correlated with education years, verbal reasoning, and average income. Thus, the shared genetic architecture paints a grave picture of inequalities predisposing some to both ASB and Covid-19.

On a less dire but surprising note, our results for Parkinson's disease reveal that education years and average income are not always protective-the genetic correlations with Parkinson's disease were positive. Also counterintuitively, Townsend Deprivation Index, doing heavy, manual labor, and having chronic obstructive pulmonary disease were inversely genetically correlated with Parkinson's disease (implying a possible protective effect). While Parkinson's disease was null for both ASB and Covid-19, it shares genetic architecture with traits strongly associated with them. To help explain this, Frigeror et al. (2005) found that those with higher education had an increased risk and those with jobs involving more physical activity had a decreased risk for Parkinson's disease ${ }^{21}$. This matches our genetic findings. Similarly, a Mendelian randomization (MR) study revealed that those with higher intelligence were less likely to engage in moderate and rigorous physical activity ${ }^{22}$. Thus, it is plausible that the protective architecture against Covid-19 and ASB that is related to more education years and higher intelligence (proxied by both education years and verbal reasoning) is likely not from greater physical activity. This lends more credence to the hypothesis proposed above that the 
medRxiv preprint doi: https://doi.org/10.1101/2021.10.18.21265145; this version posted October 19, 2021. The copyright holder for this preprint (which was not certified by peer review) is the author/funder, who has granted medRxiv a license to display the preprint in perpetuity.

All rights reserved. No reuse allowed without permission.

component of education that is protective against ASB and Covid-19 is through greater understanding and reasoning ability.

While we observed positive genetic correlations between ASB and the psychiatric and violence-related traits we measured, none of these traits were genetically correlated with Covid19. This comports with a meta-analytic review of mood disorders and risk for Covid-19 in 91 million individuals; Ceban et al. (2021) found no association between pre-existing mood disorders and susceptibility to Covid- $19^{23}$.

Our study has limitations, which must be considered. The SNP heritability estimates for both measures of Covid-19, while $>0$, were small. Second is that genetic correlations, while being robust against environmental confounders, can still suffer from genetic sources of confounding (i.e., even with genetic correlations, correlation is not always causation). To this point, we think it is highly unlikely that not being breastfed as a baby and eating less cheese cause ASB. In fact, we chose these dietary traits to illustrate this very point. Rather, the shared genetic architecture that these have with education years, verbal reasoning, and average income are the more plausibly causal phenomena. Third, we cannot determine the direction of causality with genetic correlations alone. For much of the discussion above, we tacitly presumed plausible directions of effect (e.g., ASB causing Covid-19 versus Covid-19 causing ASB). But with all the traits in our matrix, the prevailing direction of effect could be the opposite and/or some level of bi-directional causation may exist ${ }^{15,24}$. These uncertainties are avenues for future research. Specifically, at present MR cannot be leveraged to test whether ASB causes any of the traits investigated, since few genome-wide significant signals have been found for ASB. But once they are found, bi-directional MR can be used to decipher the prevailing directions. A fourth limitation is that our findings are limited to those of European ancestry. 
medRxiv preprint doi: https://doi.org/10.1101/2021.10.18.21265145; this version posted October 19, 2021. The copyright holder for this preprint (which was not certified by peer review) is the author/funder, who has granted medRxiv a license to display the preprint in perpetuity.

All rights reserved. No reuse allowed without permission.

The limitations notwithstanding, genetic correlations obtained from LDSC are not affected by sample overlap (i.e., participants being in both GWA studies for which the genetic

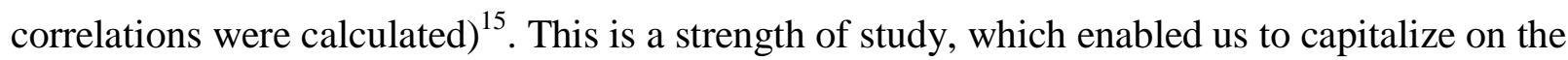
power of large, population-based cohorts and publicly available GWA data to probe timely questions. Another strength of our study is that it weaves together its empirical findings with a considerable discussion, albeit a nascent one, about ethical implications.

To conclude, ASB may reflect evolved strategies for procuring resources, perhaps in settings where it is more advantageous to provision most often for oneself while remaining wary of others, where threat-sensitivity and aggression may provide an edge $\mathrm{e}^{25,26}$. We hope our study, which is by no means comprehensive, raises interest in this issue further, along with the general importance of studying the etiology of ASB; that it contributes to existing bioethical, medical, and public-health discussions about pandemic control; and that it gets us closer to providing some measure of both protection and relief to a large part of the global population-both those engaged in ASB and those devastated by it.

\section{References}

1. Cohen MA. The Costs of Crime and Justice. 2nd edition. New York, New York: Routledge; 2020.

2. Koegl CJ, FDP. Estimating the monetary cost of risk factors for crime in boys using the EARL-20B. Psychological Services 2019;

3. O'Connell K, Berluti K, Rhoads SA, Marsh AA. Reduced social distancing early in the Covid-19 pandemic is associated with antisocial behaviors in an online United States sample. PLoS ONE 2021;16(1 January).

4. Carvalho L de F, Machado GM. Differences in adherence to Covid-19 pandemic containment measures: psychopathy traits, empathy, and sex. Trends Psychiatry Psychother. 2020;42(4):389-92.

5. Nivette A, Ribeaud D, Murray A, et al. Non-compliance with Covid-19-related public health measures among young adults in Switzerland: insights from a longitudinal cohort study. Soc Sci Med 2021;268.

6. Burt SA. Are there meaningful etiological differences within antisocial behavior? Results of a meta-analysis. Clin Psychol Rev. 2009;29(2):163-78. 
7. Polderman TJC, Benyamin B, de Leeuw CA, et al. Meta-analysis of the heritability of human traits based on fifty years of twin studies. Nat Genet 2015;47(7):702-9.

8. Rhee SH, Waldman ID. Genetic and environmental influences on antisocial behavior: A meta-analysis of twin and adoption studies. Psychol Bull 2002;128(3):490-529.

9. Tielbeek JJ, Barnes JC, Popma A, et al. Exploring the genetic correlations of antisocial behaviour and life history traits. BJPsych Open 2018;4(6):467-70.

10. Ip HF, van der Laan CM, Krapohl EML, et al. Genetic association study of childhood aggression across raters, instruments, and age. Transl Psychiatry 2021;11(1).

11. Tielbeek JJ, Johansson A, Polderman TJC, et al. Genome-wide association studies of a broad spectrum of antisocial behavior. JAMA Psychiatry 2017;74(12):1242-50.

12. Massoglia M, Pridemore WA. Incarceration and health. Annu Rev Sociol 2015;41:291310.

13. Vaughn MG, Salas-Wright CP, Delisi M, Maynard BR, Boutwell B. Prevalence and correlates of psychiatric disorders among former juvenile detainees in the United States. Compr Psychiatry 2015;59:107-16.

14. Tielbeek JJ, Boutwell BB. Exploring the genomic architectures of health, physical traits and antisocial behavioral outcomes: a brief report. Front Psychiatry 2020;11.

15. Bulik-Sullivan B, Finucane HK, Anttila V, et al. An atlas of genetic correlations across human diseases and traits. Nat Genet 2015;47(11):1236-41.

16. Hokayem C, Krohn E, Unrath M. Fewer low-wage full-time, year-round workers during Covid-19 causes Increase in median earnings among those still employed [Internet].

United States Census Bureau. 2021 [cited 2021 Oct 4];Available from: https://www.census.gov/library/stories/2021/09/workers-earnings-decline-overall-duringpandemic-but-increase-for-full-time-year-round-workers.html

17. Frey A, Verhagen MD. Learning loss due to school closures during the Covid-19 pandemic. Proc Natl Acad Sci USA [Internet] 2020;118(17). Available from: https://doi.org/10.1073/pnas.2022376118

18. Anser MK, Yousaf Z, Nassani AA, Alotaibi SM, Kabbani A, Zaman K. Dynamic linkages between poverty, inequality, crime, and social expenditures in a panel of 16 countries: two-step GMM estimates. J Econ Struct 2020;9(1).

19. Abrevaya J, Mulligan K. Effectiveness of state-level vaccination mandates: Evidence from the varicella vaccine. J Health Econ 2011;30(5):966-76.

20. Lawler EC. Effectiveness of vaccination recommendations versus mandates: Evidence from the hepatitis A vaccine. J Health Econ 2017;52:45-62.

21. Frigerio R, Elbaz A, Sanft K, et al. Education and occupations preceding Parkinson disease. Neurology 2005;22(65):1575-83.

22. Davies NM, Hill D, Anderson EL, Sanderson E, Deary IJ, Smith GD. Multivariable twosample Mendelian randomization estimates of the effects of intelligence and education on health. 2019; Available from: https://doi.org/10.7554/eLife.43990.001

23. Ceban F, Nogo D, Carvalho IP, et al. Association between mood disorders and risk of Covid-19 infection, hospitalization, and death: a systematic review and meta-analysis. JAMA Psychiatry 2021;

24. Hemani G, Bowden J, Davey Smith G. Evaluating the potential role of pleiotropy in Mendelian randomization studies. Human Mol Genet. 2018;27(R2):R195-208.

25. Gilbert P, Basran J. The evolution of prosocial and antisocial competitive behavior and the emergence of prosocial and antisocial leadership styles. Front Psychol. 2019;10(JUN). 
medRxiv preprint doi: https://doi.org/10.1101/2021.10.18.21265145; this version posted October 19, 2021. The copyright holder for this preprint

(which was not certified by peer review) is the author/funder, who has granted medRxiv a license to display the preprint in perpetuity.

All rights reserved. No reuse allowed without permission.

26. Dinić BM, Bodroža B. Covid-19 protective behaviors are forms of prosocial and unselfish behaviors. Front Psychol 2021;12.

27. Hemani G, Zheng J, Elsworth B, et al. The MR-Base platform supports systematic causal inference across the human phenome. Elife [Internet] 2018;30(7):e34408-undefined.

Available from: https://doi.org/10.7554/eLife.34408.001

28. Lyon M, Andrews S, Elsworth B, Gaunt T, Hemani G, Marcora E. The variant call format provides efficient and robust storage of GWAS summary statistics. bioRxiv 2020;

29. Elsworth B, Lyon M, Alexander T, et al. The MRC IEU OpenGWAS data infrastructure. bioRxiv [Internet] 2020;Available from: https://doi.org/10.1101/2020.08.10.244293

30. Okbay A, Beauchamp JP, Fontana MA, et al. Genome-wide association study identifies 74 loci associated with educational attainment. Nature 2016;533(7604):539-42.

31. Karlsson Linnér R, Biroli P, Kong E, et al. Genome-wide association analyses of risk tolerance and risky behaviors in over 1 million individuals identify hundreds of loci and shared genetic influences. Nat Genet 2019;51(2):245-57.

32. Zenin A, Tsepilov Y, Sharapov S, et al. Identification of 12 genetic loci associated with human healthspan. Commun Biol 2019;2(1).

33. Timmers PR, Mounier N, Lall K, et al. Genomics of 1 million parent lifespans implicates novel pathways and common diseases and distinguishes survival chances. eLife [Internet] 2019;15(8:e39856). Available from: https://doi.org/10.7554/eLife.39856.001

34. Nalls MA, Blauwendraat C, Vallerga CL, et al. Identification of novel risk loci, causal insights, and heritable risk for Parkinson's disease: a meta-analysis of genome-wide association studies. Lancet Neurol 2019;18(12):1091-102.

35. Covid-19 Host Genetics Initiative. Mapping the human genetic architecture of Covid-19. Nature 2021.

Table 1. Data sources.

\begin{tabular}{c|c|c}
\hline $\begin{array}{c}\text { Trait } \\
\text { (abbreviation) }\end{array}$ & Data source: consortium and availability & Effective Sample size \\
\hline $\begin{array}{c}\text { Average total household } \\
\text { income before tax }\end{array}$ & MRC-IEU; IEU Open GWAS Project identifier: ukb-b- & 397,751 \\
("average income") & $7408 ;$ https://gwas.mrcieu.ac.uk/datasets/ ${ }^{27-29}$ & \\
\hline Education years & Okbay et al. $(2016)^{30} ;$ Social Science Genetic Association & 293,723 \\
& Consortium $(\mathrm{SSGAC}) ;$ https://www.thessgac.org/ ${ }^{31}$ & \\
\hline Healthspan & Zenin et al. $(2019)^{32} ;(\mathrm{UKBB} ; \mathrm{n}=300,447$ European); & 300,447 \\
\hline
\end{tabular}


medRxiv preprint doi: https://doi.org/10.1101/2021.10.18.21265145; this version posted October 19, 2021. The copyright holder for this preprint (which was not certified by peer review) is the author/funder, who has granted medRxiv a license to display the preprint in perpetuity.

All rights reserved. No reuse allowed without permission.

\begin{tabular}{|c|c|c|}
\hline $\begin{array}{l}\text { (living free from congestive } \\
\text { heart failure; myocardial } \\
\text { infarction, chronic } \\
\text { obstructive pulmonary } \\
\text { disease, stroke, dementia, } \\
\text { diabetes, cancer, and death) }\end{array}$ & https://www.gwasarchive.org/ & \\
\hline Lifespan & $\begin{array}{l}\text { Timmers et } \text { al. }^{33} \text { (2019); UKBB/LifeGen study; } \\
\text { https://datashare.ed.ac.uk/handle/10283/3209 }\end{array}$ & $1,012,240$ \\
\hline $\begin{array}{l}\text { Word interpolation } \\
\text { ("Verbal reasoning") }\end{array}$ & $\begin{array}{l}\text { UKBB/Neale lab; IEU Open GWAS Project identifier: } \\
\text { ukb-d-4957; https://gwas.mrcieu.ac.uk/datasets/ }{ }^{27-29}\end{array}$ & $\begin{array}{l}98,753 \text { cases and } 18,062 \\
\text { controls }\end{array}$ \\
\hline Breastfed as baby & $\begin{array}{l}\text { MRC-IEU; IEU Open GWAS Project identifier: ukb-b- } \\
\text { 13423; https://gwas.mrcieu.ac.uk/datasets/ }{ }^{27-29}\end{array}$ & $\begin{array}{l}251,150 \text { cases and } 100,94 \\
\text { controls }\end{array}$ \\
\hline Cheese intake & $\begin{array}{l}\text { MRC-IEU; IEU Open GWAS Project identifier: ukb-b- } \\
\text { 1489; https://gwas.mrcieu.ac.uk/datasets/ }{ }^{27-29}\end{array}$ & 451,486 \\
\hline $\begin{array}{l}\text { Happiness } \\
\text { (self-rated: "In general how } \\
\text { happy are you?") }\end{array}$ & $\begin{array}{l}\text { UKBB/Neale lab; IEU Open GWAS Project identifier: } \\
\text { ukb-a-367; https://gwas.mrcieu.ac.uk/datasets/ }{ }^{27-29}\end{array}$ & 110,935 \\
\hline Parkinson's disease & $\begin{array}{l}\text { Nalls et al. }(2019)^{34} \text {. International Parkinson's Disease } \\
\text { Genomics Consortium; IEU Open GWAS Project } \\
\text { identifier: ieu-b-7; https://gwas.mrcieu.ac.uk/datasets/ }{ }^{27-29}\end{array}$ & $\begin{array}{l}33,674 \text { cases and } 449,046 \\
\text { controls }\end{array}$ \\
\hline $\begin{array}{l}\text { Coronavirus disease } 2019 \\
\text { (Covid-19), a contagious } \\
\text { disease caused by severe }\end{array}$ & $\begin{array}{l}\text { Covid-19 Host Genetics Initiative, release } 4^{35} \text {; IEU Open } \\
\text { GWAS Project identifier: ebi-a-GCST010780; } \\
\text { https://gwas.mrcieu.ac.uk/datasets/ }{ }^{27-29}\end{array}$ & $\begin{array}{l}\text { 14,134 Covid- } 19 \text { cases anı } \\
1,284,876 \text { controls (releası } \\
\text { 4) }\end{array}$ \\
\hline
\end{tabular}


medRxiv preprint doi: https://doi.org/10.1101/2021.10.18.21265145; this version posted October 19, 2021. The copyright holder for this preprint (which was not certified by peer review) is the author/funder, who has granted medRxiv a license to display the preprint in perpetuity.

All rights reserved. No reuse allowed without permission.

\begin{tabular}{|c|c|c|}
\hline $\begin{array}{c}\text { acute respiratory } \\
\text { syndrome coronavirus } 2\end{array}$ & $\begin{array}{l}\text { Covid-19 Host Genetics Initiative, release } 6^{35} \\
\text { https://www.covid19hg.org/results/r6/ }\end{array}$ & $\begin{array}{c}\text { SNPs }=12,500,447 \\
112,612 \text { Covid- } 19 \text { cases an } \\
2,474,079 \text { controls (releas } \\
6) \\
\text { SNPs }=8,141,092\end{array}$ \\
\hline $\begin{array}{l}\text { Job involves heavy manual } \\
\text { or physical work } \\
\text { ("Heavy, manual labor") }\end{array}$ & $\begin{array}{l}\text { MRC-IEU; IEU Open GWAS Project identifier: ukb-b- } \\
\text { 2002; https://gwas.mrcieu.ac.uk/datasets/ }{ }^{27-29}\end{array}$ & 263,615 \\
\hline Noisy workplace & $\begin{array}{l}\text { MRC-IEU; IEU Open GWAS Project identifier: ukb-b- } \\
\text { 2091; https://gwas.mrcieu.ac.uk/datasets/ }{ }^{27-29}\end{array}$ & 151,624 \\
\hline $\begin{array}{l}\text { Antisocial behavior } \\
\text { (ASB) }\end{array}$ & $\begin{array}{l}\text { Broad Antisocial Behavior Consortium (BroadABC); } \\
\text { http://broadabc.ctglab.nl/ (data available upon request) }{ }^{11}\end{array}$ & 56,575 \\
\hline $\begin{array}{l}\text { Townsend Deprivation } \\
\text { Index }\end{array}$ & $\begin{array}{c}\text { MRC-IEU; IEU Open GWAS Project identifier: ukb-b- } \\
10011 ; \\
\text { https://gwas.mrcieu.ac.uk/datasets/ } /^{27-29}\end{array}$ & 462,464 \\
\hline Gastrointestinal diseases & $\begin{array}{l}\text { FINNGen Biobank analysis; 39,639 cases and 56,860 } \\
\text { controls (European); binary; IEU Open GWAS Project } \\
\text { identifier: finn-a-K11_GIDISEASES; } \\
\text { https://www.finngen.fi/fi }{ }^{27-29}\end{array}$ & $\begin{array}{l}39,639 \text { cases and } 56,860 \\
\text { controls }\end{array}$ \\
\hline $\begin{array}{c}\text { Chronic obstructive } \\
\text { pulmonary disease (COPD) } \\
\text { differential diagnosis }\end{array}$ & $\begin{array}{l}\text { UKBB/Neale lab; IEU Open GWAS Project identifier: } \\
\text { ukb-d-COPD_EXCL; https://gwas.mrcieu.ac.uk/datasets/27- } \\
29\end{array}$ & $\begin{array}{c}26,710 \text { cases and } 334,484 \\
\text { controls }\end{array}$ \\
\hline Genitourinary diseases & $\begin{array}{l}\text { UKBB/Neale lab; IEU Open GWAS Project identifier: } \\
\text { ukb-d-XIV_GENITOURINARY; }\end{array}$ & 71,620 cases and 289,574 \\
\hline
\end{tabular}




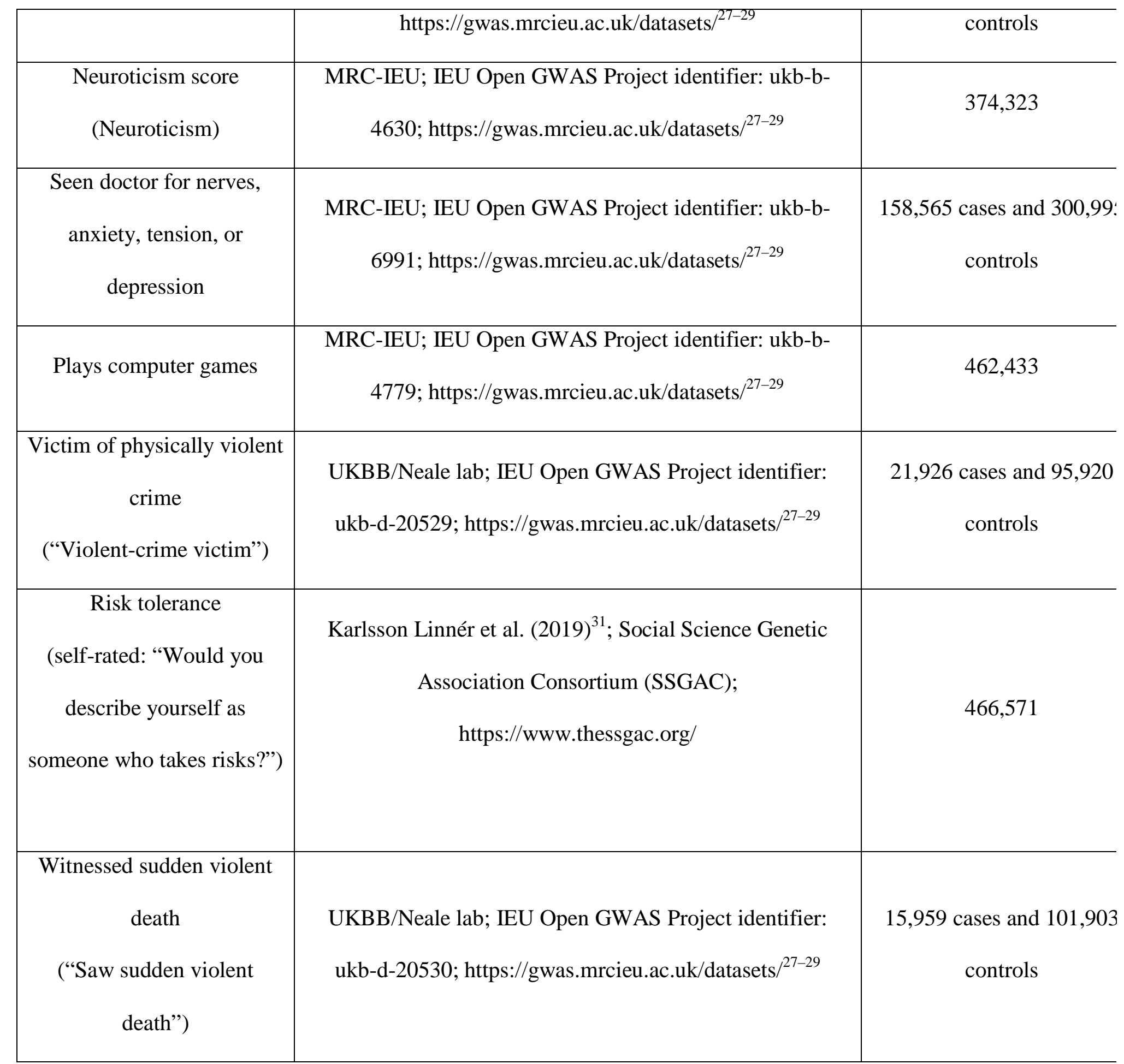

$\mathrm{UKBB}=\mathrm{UK}$ Biobank; IEU=Medical Research Counsel Integrative Epidemiology Unit at the University of Bristol. 
medRxiv preprint doi: https://doi.org/10.1101/2021.10.18.21265145; this version posted October 19, 2021. The copyright holder for this preprint (which was not certified by peer review) is the author/funder, who has granted medRxiv a license to display the preprint in perpetuity. All rights reserved. No reuse allowed without permission.

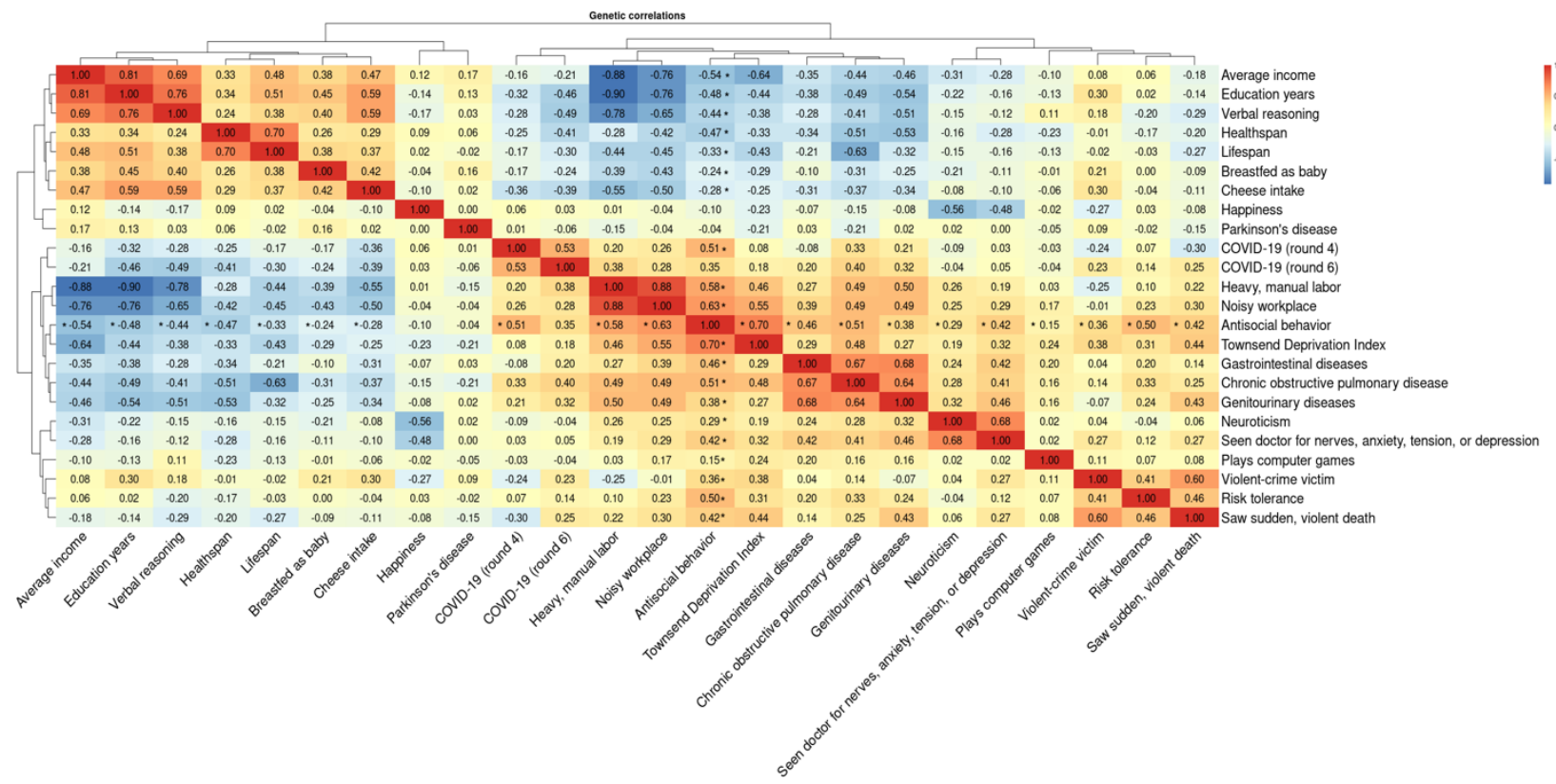

Figure 1. Heatmap matrix of genetic correlations for antisocial behavior and 23 traits. Asterisks are placed by the ASB findings that survived false-discovery rate (FDR) correction.

Supplementary tables 1-2 provide confidence intervals and FDR-corrected $P$-values for all traits. 
medRxiv preprint doi: https://doi.org/10.1101/2021.10.18.21265145; this version posted October 19, 2021. The copyright holder for this preprint (which was not certified by peer review) is the author/funder, who has granted medRxiv a license to display the preprint in perpetuity. All rights reserved. No reuse allowed without permission.

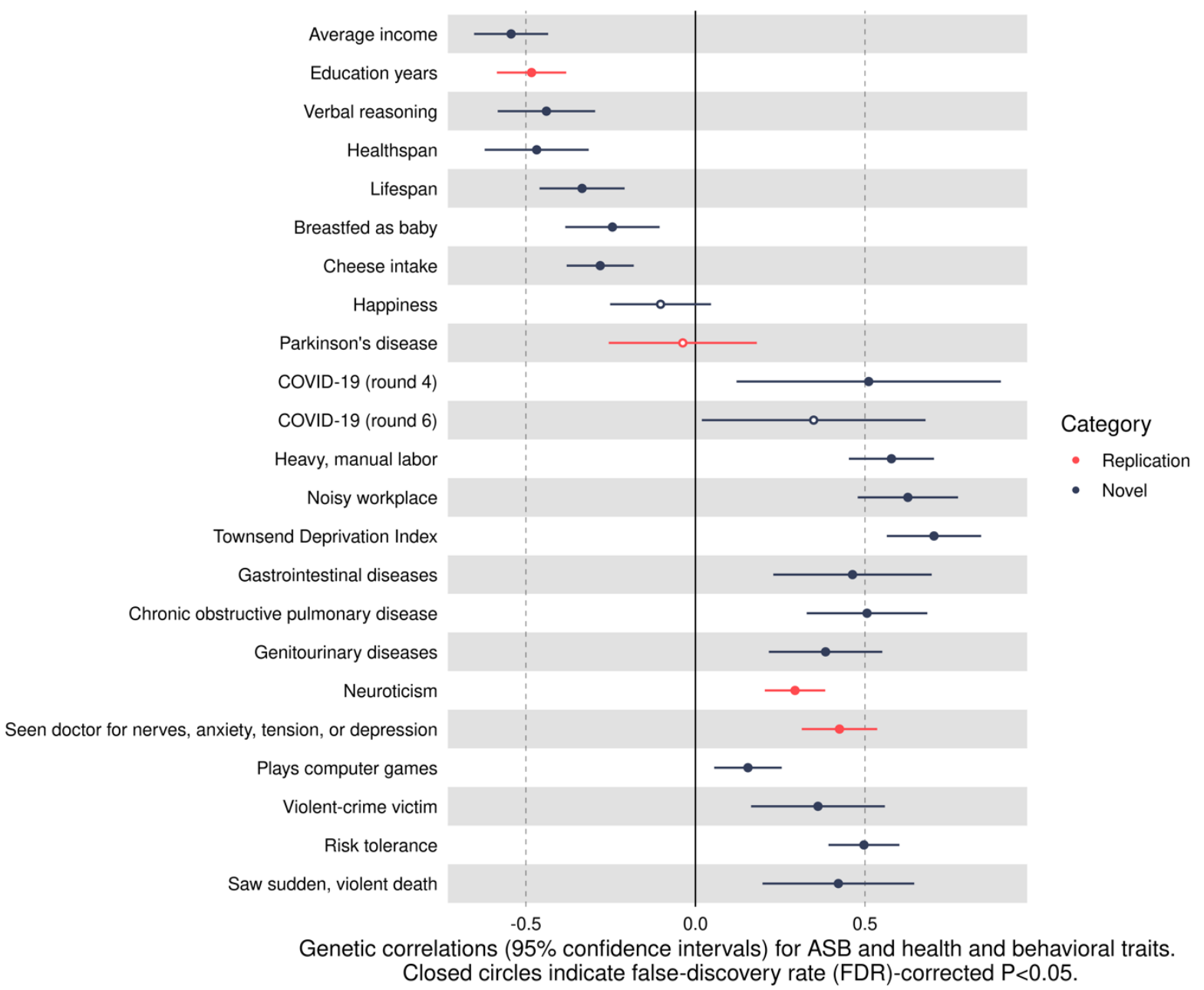

Figure 2. Forest plot of genetic correlations (95\% confidence intervals) between ASB and 23

traits. Closed circles indicate genetic correlations with significant $P$-values after false-discovery rate (FDR) correction. 
medRxiv preprint doi: https://doi.org/10.1101/2021.10.18.21265145; this version posted October 19, 2021. The copyright holder for this preprint (which was not certified by peer review) is the author/funder, who has granted medRxiv a license to display the preprint in perpetuity. All rights reserved. No reuse allowed without permission.

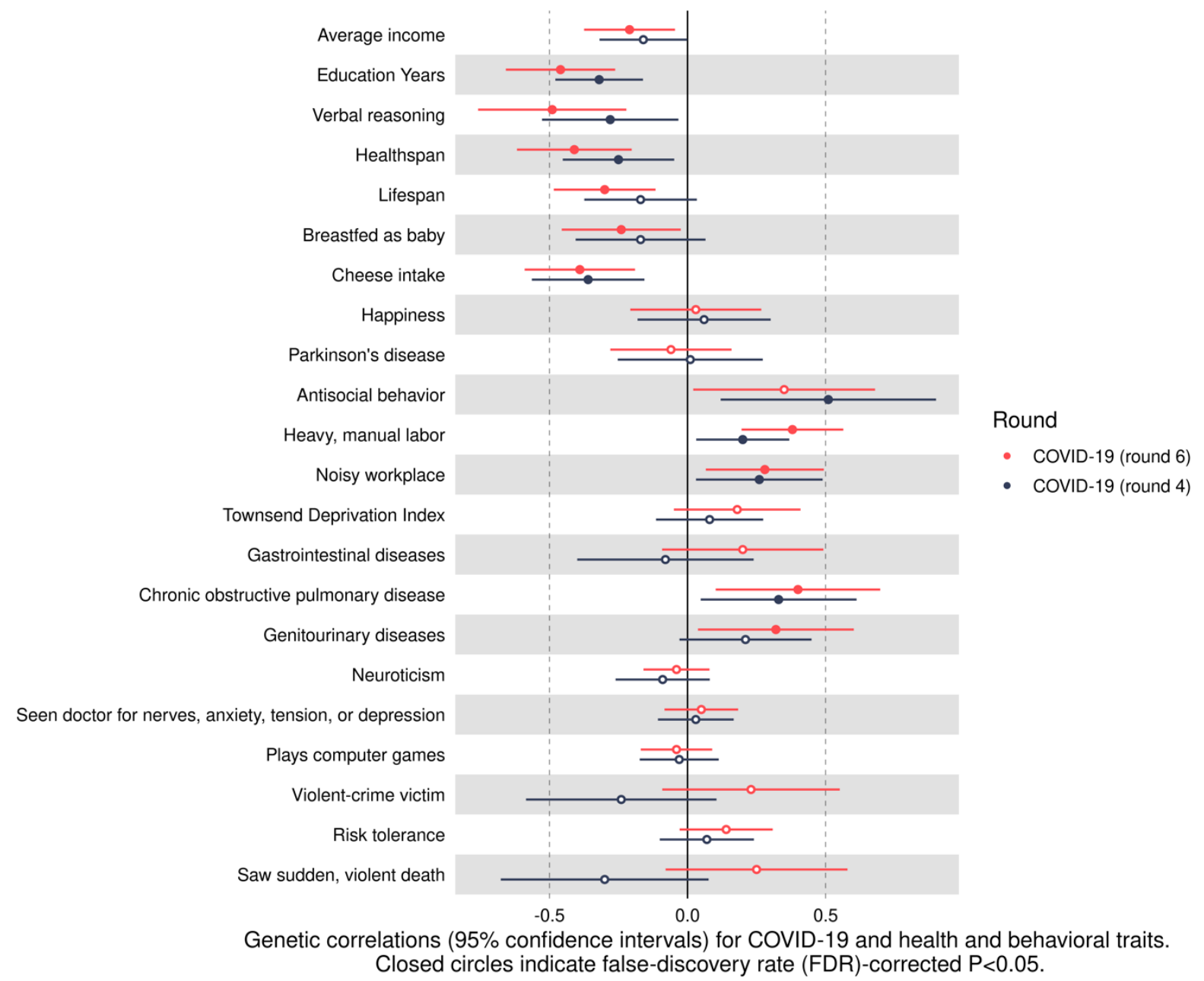

Figure 3. Forest plot of genetic correlations (95\% confidence intervals) between Covid-19

(rounds 4 and 6) and health and behavioral traits. Closed circles indicate genetic correlations with significant $P$-values after false-discovery rate (FDR) correction. 